\title{
Treatment of Terminal Renal Failure in Children by Home Dialysis and Transplantation
}

\author{
J. M. BOULTON JONES, J. S. CAMERON, M. BEWICK, C. S. OGG, S. R. MEADOW, and \\ F. G. ELLIS \\ From Guy's Hospital, London
}

\begin{abstract}
Boulton Jones, J. M., Cameron, J. S., Bewick, M., Ogg, C. S., Meadow, S. R., and Ellis, F. G. (1971). Archives of Disease in Childhood, 46, 457. Treatment of terminal renal failure in children by home dialysis and transplantation. Eleven children, aged 6 to 17 years, suffering from irreversible renal failure, were treated by regular haemodialysis. This was preparatory to renal transplantation in 6 children. During periods of 8 to 26 months none of these patients have died. Both regular haemodialysis and transplantation present unsolved problems. With dialysis, the relation between the diet, amount of dialysis, growth, and sexual development have still to be worked out. With transplantation, better ways of achieving good and controlled immunosuppression must be found. In both types of treatment, the psychological and social trauma to both the patients and their families must be evaluated and treated.
\end{abstract}

Regular haemodialysis and renal transplantation are now effective methods of treating adults who have terminal renal failure (Lancet, 1970). Only a small number of children have been subjected to these treatments, though between 1 and 6 children per million population die of renal failure every year (Meadow, Cameron, and Ogg, 1970; Potter et al., 1970). There are ethical, technical, and developmental difficulties in attempting to treat these children, and only a few centres have undertaken the responsibility. In this paper we report our experience with 11 children, aged 6 to 17 years of age, who have been treated by regular haemodialysis, followed in 6 cases by renal transplantation.

\section{Selection of Patients}

Theoretically, this is even more difficult than with adults because the whole family will be involved. All our patients have both parents alive. The parents of two boys had separated but agreed to live together to help with treatment. All but one patient (who was herself adopted) had at least one sib. In two families one other sib was also suffering from some other chronic disease. Only one child was rejected because of family circumstances. Once the decision to treat the child had been taken, the parents were led to expect prolonged dialysis before transplantation. No parent has yet refused treatment on behalf of their child-whatever their

Received 22 February 1971. misgivings. Therefore, the decision of whether to treat or not is effectively taken by the medical staff before even approaching the parents on the subject. No formal psychiatric preassessment has been made routinely.

The very few medical contraindications are the same as those in adults. The child should be free of other serious conditions and the cause of the renal failure should not be a systemic disease, though one of our patients had a history suggestive of systemic lupus erythematosus which could not be proven. Accelerated hypertension is not a contraindication.

Peritoneal dialysis was used in most of our patients initially. Two patients presented with acute renal failure and were maintained on peritoneal dialysis while this was investigated and being treated unsuccessfully. The patients who were previously known to have chronic renal failure had a shorter period of peritoneal dialysis, while a Scribner shunt was being inserted.

\section{Haemodialysis}

Shunts. Standard Scribner PTFE-silastic arteriovenous shunts were used, including the smallest adult size vessel tips (No. 17). The arterial side was inserted into the radial artery in all but two patients, who were thought to be too small; in them the brachial artery was used. No sign of arterial insufficiency was noted subsequently in the hand. Surprisingly, the life of a shunt in a child is as good as in an adult. In 95 patientmonths in our 11 patients, an artery has only been sacrificed 5 times, and 3 of these were in 1 patient (Case 8). 
In 2 patients (Cases 5 and 8) a femoral shunt was fashioned. A short length of saphenous vein was removed and one end anastomosed to the side of the femoral artery. The arterial tip of the shunt was secured into the other end and the venous tip into the proximal part of the saphenous vein. This was very successful in both patients.

Cimino fistulae. Subcutaneous arteriovenous fistulae (Brescia et al., 1966) were made on 7 occasions in 6 patients. This enables the 'arterialized' vein to be cannulated before each dialysis and thereby avoids the physical limitations imposed by a shunt. These fistulae have been used successfully in children before (Linstedt, Lindengård, and Lindholm, 1970). Of the 7 Cimino fistulae fashioned, 4 have produced a satisfactory result but only one was used routinely. The patient became so upset by the procedure of cannulation required for each dialysis, that an anaesthetizing dose of diazepam had to be given each time.

Maintenance haemodialysis was carried out using a standard two-layer Kiil dialyser (surface area $1.0 \mathrm{~m}^{2}$ ) in all but 2 children (Cases 4 and 5). One or two boards were used according to the ultrafiltration required. If two boards were used, one was washed back two hours before the end of each dialysis. The two smallest patients (Cases 4 and 5) were dialysed with a paediatric Kiil $\left(0.6 \mathrm{~m}^{2}\right)$. The duration of each dialysis varied between $2 \times 10$ hours and $3 \times 12$ hours. Standard blood lines were used in all but one patient (see later). Cellulose PT 300 membranes were used in all patients except one (Case 4), who was changed to PT 150 Cuprophane to increase ultrafiltration. Dialysis was carried out over-night.

Diet. Two patients (Cases 2 and 5) were given an almost free diet but avoided food rich in potassium (see Table I for details). In general the children cooperated well with their diets. Fluid was restricted to
200-500 ml/24 hours. The calorie intakes were as chosen by mother and child, and we should now regard these as inadequate in Cases 1,2 , and 3.

Bilateral nephrectomy. Initially the policy of the unit was to perform bilateral nephrectomy on all patients because all were awaiting renal transplantation. 6 bilateral nephrectomies were done for this reason. 3 of these patients also had had chronic pyelonephritis with reflux, which was a further indication for the operation. Case 4 underwent the operation for accelerated hypertension (Vertes et al., 1969; British Medical Journal, 1969). Since the expansion of the home dialysis programme, bilateral nephrectomy has not been performed routinely and the remaining 4 patients still retain their kidneys.

\section{Transplantation}

Source of donor kidneys. Eight homografts were inserted into 6 patients: 2 were donated by parents (Case 10 from mother; Case 7 from father), and 6 were cadavers' kidneys; one of these, coming from a 4-yearold boy, was transplanted into Case 11; the rest came from adults.

Tissue typing. This was carried out using the Bristol and Batchelor Plates (Batchelor and Joysey, 1969).

Operation. A midline incision was used on 5 occasions when the kidney was placed intraperitoneally. An extraperitoneal approach through an oblique incision was used for the last 3 operations. In 5 patients the arterial anastomosis was made end-to-end between the donor's renal artery and the recipient's common iliac artery and end-to-end using the recipient's internal iliac artery for three operations (the second grafts of Cases 8 and 9). The venous anastomosis was made

TABLE I

Summary of Clinical Details of 5 Patients on Long-term Haemodialysis

\begin{tabular}{|c|c|c|c|c|c|c|c|c|c|c|}
\hline \multirow[b]{2}{*}{$\begin{array}{l}\text { Case } \\
\text { No. }\end{array}$} & \multirow[b]{2}{*}{ Diagnosis } & \multirow[b]{2}{*}{$\underset{(y r)}{\text { Duration }}$} & \multirow[b]{2}{*}{$\begin{array}{c}\text { Age on } \\
\text { Admission } \\
\quad(y r)\end{array}$} & \multirow[b]{2}{*}{ Sex } & \multirow[b]{2}{*}{$\begin{array}{c}\text { Months } \\
\text { on } \\
\text { Dialysis }\end{array}$} & \multirow[b]{2}{*}{ Shunt Sites } & \multicolumn{4}{|c|}{ Diet as Taken } \\
\hline & & & & & & & $\begin{array}{l}\text { Protein } \\
\text { (g/kg per } \\
\text { day) }\end{array}$ & $\begin{array}{l}\text { Calories } \\
\text { (kg/day) }\end{array}$ & $\begin{array}{l}\underset{\text { Sodium }}{\text { (mEq/kg }} \\
\text { per day) }\end{array}$ & $\begin{array}{l}\text { Potassium } \\
(\mathrm{mEq} / \mathbf{k g})\end{array}$ \\
\hline 1 & $\begin{array}{l}\text { CGN (biopsy) } \\
\text { ? SLE }\end{array}$ & $2 \cdot 5$ & $15 \cdot 7$ & $\mathbf{F}$ & 19 & $\begin{array}{l}\text { Right forearm; } \\
\text { left Cimino }\end{array}$ & $1 \cdot 3$ & 42 & 0.5 & $1 \cdot 2$ \\
\hline 2 & $\begin{array}{l}\text { CGN (biopsy); } \\
\text { focal glomer- } \\
\text { ulosclerosis }\end{array}$ & $1 \cdot 2$ & $16 \cdot 5$ & $\mathbf{F}$ & 13 & $\begin{array}{l}\text { Right forearm; } \\
\text { failed left } \\
\text { Cimino }\end{array}$ & $2 \cdot 0$ & 45 & Free & Free \\
\hline 3 & CGN (biopsy) & $4 \cdot 3$ & $13 \cdot 6$ & $\mathbf{M}$ & 8 & $\begin{array}{l}\text { Right forearm; } \\
\text { left Cimino }\end{array}$ & $1 \cdot 6$ & 39 & 0.7 & $1 \cdot 6$ \\
\hline 4 & $\begin{array}{l}\text { Accelerated } \\
\text { hypertension }\end{array}$ & $0 \cdot 8$ & $6 \cdot 3$ & $\mathbf{M}$ & 13 & Left brachial & $2 \cdot 3$ & 75 & $1 \cdot 0$ & $1 \cdot 8$ \\
\hline 5 & $\begin{array}{l}\text { Haemolytic } \\
\text { uraemic } \\
\text { syndrome }\end{array}$ & $0 \cdot 8$ & $10 \cdot 4$ & $\mathbf{F}$ & 11 & $\begin{array}{l}\text { Left brachial; } \\
\text { left femoral }\end{array}$ & $2 \cdot 7$ & 90 & Free & Free \\
\hline
\end{tabular}

CGN = Chronic glomerulonephritis; SLE = Systemic lupus erythematosus

$\star$ Duration $=$ Time between first symptom attributable to renal failure and admission to the programme. 


\section{Treatment of Terminal Renal Failure in Children by Home Dialysis and Transplantation 459}

end-to-side between the renal vein and the common iliac vein on all occasions. The donor ureter was implanted into the bladder using the Politano-Leadbetter technique (Politano and Leadbetter, 1958).

Immunosuppression. Azathioprine $5 \mathrm{mg} / \mathrm{kg}$ and prednisone $100 \mathrm{mg}$ were given from the day of operation. Azathioprine was reduced to $2 \mathrm{mg} / \mathrm{kg}$ per day after 4 days. This dose was maintained unless the white cell count fell below $4000 / \mathrm{mm}^{3}$, when it was stopped until the white cell count rose again. Prednisone was reduced at intervals, aiming at a dose of $5-10 \mathrm{mg} /$ day after 3 months. Rejection episodes were detected by the usual methods (Chisholm et al., 1969), and treated by increasing the prednisone to $100 \mathrm{mg} /$ day, and giving actinomycin C $200 \mu \mathrm{g} /$ day i.v. and 150 rads of DXT to the graft/day for 3 days. Antilymphocyte globulin was used to treat chronic rejection in Cases 8 and 9 . Latterly, a Rosette Inhibition Test has been used to help control the level of immunosuppression (Munro et al., 1971). Immune enhancement was used in one patient (Case 10) and has been described elsewhere (Batchelor et al., 1970).

\section{Results}

Of the 11 children, 5 have been on long-term haemodialysis, 4 of these in their homes. It is hoped that the fifth will be moved home shortly. The other 6 have received periods of haemodialysis, totalling 31 months, while awaiting their transplant, or between transplants.

Medical considerations of long-term haemodialysis. This section is concerned with the 5 patients on long-term dialysis. They have received a total of 64 months of dialysis.

(1) Nutritional state and diet. Anorexia and weight loss are commonly associated with chronic renal failure. Two patients (Cases 2 and 5) were frankly cachectic when starting haemodialysis. Case 5 had a long period of peritoneal dialysis ( 5 weeks) during which she ate very little, vomited a lot, and had severe diarrhoea. When she began haemodialysis she weighed $14 \mathrm{~kg}$ (normal for age about $30 \mathrm{~kg}$ ), and was also below the third centile for height. After 7 months of haemodialysis she had put on $6 \mathrm{~kg}$. Case 2 had increasing renal failure associated with massive proteinuria (up to $60 \mathrm{~g} /$ day). When she started haemodialysis she weighed $44 \mathrm{~kg}$; after 12 months her weight had increased by $10 \mathrm{~kg}$. These were the two most dramatic examples; both were allowed a free diet, and both had a little residual renal function (GFR $=3 \mathrm{ml} / \mathrm{min}$ ). However, the other patients showed a similar trend. During 64 months of dialysis these 5 children put on a total of $35 \mathrm{~kg}$. This shows that they are anabolic and permits a com- paratively large protein intake. Hyperkalaemia has not been a problem.

(2) Hypertension. This was a problem in 4 of the 5 patients. In 2 it was symptomless and was easily controlled by decreasing the sodium intake and increasing the ultrafiltration during dialysis. Case 5 required hypotensive agents as well. On one occasion she was admitted unconscious, with fits, and a diastolic pressure of $130 \mathrm{mmHg}$. She responded well to intravenous hydralazine, and presumably the episode could have been averted with earlier action. Case 4 presented with accelerated hypertension which was impossible to control with the usual measures. He usually began dialysis with a diastolic pressure of $110 \mathrm{mmHg}$ and received vigorous ultrafiltration. It was common for him to have a period of hypotension towards the end of dialysis, but after the blood had been washed back from the kidney he was hypertensive again. For this reason his blood lines were shortened to a minimal practical length. This reduced the volume washed back by about $15 \%$ but still did not control his blood pressure satisfactorily. Hypotensive drugs did not help. Therefore, he underwent a bilateral nephrectomy, after which his blood pressure was easy to control without drugs.

(3) Anaemia. The haematocrit of these children varied between 15 and $28 \%$ without transfusion. All received folic acid $5 \mathrm{mg} /$ day (because it is dialysable) and iron dextran $50 \mathrm{mg}$ intravenously once a fortnight (Fam et al., 1970). This degree of chronic anaemia produces few limitations on patients of this age group.

(4) Infections. Case 4 developed an abscess in the left renal bed after his nephrectomy. This required drainage. Case 1 is the only one to have developed hepatitis; as usual in those on dialysis, it produced few symptoms. The hepatitis associated $\mathrm{Au}-\mathrm{SH}$ antigen was never detected. Cases 1,2 , and 3 had shunt site infections requiring systemic antibiotics.

(5) Secondary hyperparathyroidism. None of these 5 has radiological evidence of hyperparathyroidism, but Case 1 has a consistently raised plasma calcium $(10 \cdot 5-11 \mathrm{mg} / 100 \mathrm{ml})$, without symptoms.

Growth. Only one child (Case 5) was below the third centile for height when starting dialysis. She has shown no evidence of catch-up growth. In fact she has only grown $1 \mathrm{~cm}$ in 6 months. Cases 1,2, and 3 have not grown on dialysis over a period of 8,19 , and 13 months, respectively. 
Summary of Clinical Details of 6 Pätien

\begin{tabular}{|c|c|c|c|c|c|c|c|}
\hline Case No. & Diagnosis & $\begin{array}{l}\text { Duration } \\
\text { of Symptoms } \\
\text { (yr) }\end{array}$ & $\begin{array}{c}\text { Age on } \\
\text { Admission } \\
(y \mathbf{r})\end{array}$ & Sex & $\begin{array}{l}\text { Months } \\
\text { on } \\
\text { Dialysis }\end{array}$ & $\begin{array}{c}\begin{array}{c}\text { Date } \\
\text { of } \\
\text { Transplantation }\end{array} \\
\end{array}$ & 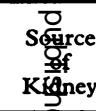 \\
\hline $\begin{array}{l}6 \\
7 \\
8\end{array}$ & $\begin{array}{l}\text { CGN (histology from nephrectomy) } \\
\text { CPN with reflux } \\
\text { CPN with reflux }\end{array}$ & $\begin{array}{l}2 \cdot 2 \\
3 \cdot 0\end{array}$ & $\begin{array}{l}14 \cdot 3 \\
11 \cdot 6 \\
16 \cdot 0\end{array}$ & $\begin{array}{l}\mathbf{F} \\
\mathbf{F}\end{array}$ & $\begin{aligned} & 1 \\
& 2 \\
& \text { (i) } \\
& \text { (ii) } 9\end{aligned}$ & $\begin{array}{r}30.7 .69 \\
20.11 .68 \\
8.2 .69 \\
19.9 .70\end{array}$ & 舟 \\
\hline 9 & CPN & $7 \cdot 0$ & $11 \cdot 11$ & $\mathbf{M}$ & $\begin{array}{l}\text { (i) } 1 \\
\text { (ii) } 3\end{array}$ & $\begin{array}{l}3.12 .68 \\
12.5 .70\end{array}$ & $\frac{\mathrm{C}}{\mathrm{C}}$ \\
\hline $\begin{array}{l}10 \\
11\end{array}$ & $\begin{array}{l}\text { CPN with reflux } \\
\text { CGN (biopsy) }\end{array}$ & $\begin{array}{l}6 \cdot 0 \\
0 \cdot 9\end{array}$ & $\begin{array}{l}9 \cdot 3 \\
9 \cdot 8\end{array}$ & $\begin{array}{l}\mathbf{M} \\
\mathbf{M}\end{array}$ & $\begin{array}{l}7 \\
7\end{array}$ & $\begin{array}{r}4.3 .70 \\
19.5 .70\end{array}$ & $\mathscr{\mathbb { E }}^{(M}$ \\
\hline
\end{tabular}

CGN $=$ Chronic glomerulonephritis $; C P N=$ Chronic pyelonephritis $(M)=$ Mother donated one kidney; $(F)=$ Father donated one 1kid

However, both Cases 1 and 2 had probably reached their mature height before starting dialysis; they are on the 25 th centile and above the 50 th, respectively. Case 4 has grown along the 25 th centile.

Puberty. Cases 1 and 2 had started to menstruate before developing terminal renal failure. Both then developed amenorrhoea, but Case 2 restarted menstruating after 10 months of haemodialysis. Case 3 has grown pubic hair, but the other two are both prepubertal.

\section{Social and Psychiatric Aspects of Long-term Haemodialysis}

All 5 adjusted to dialysis better than many adults. One boy (Case 3) was severely depressed while in the terminal stages of renal failure but improved quickly after starting dialysis; this happens commonly (Frances, Fine, and Korsch, 1970). Obviously it is very important to avoid set backs. We have only had two reversals (nephrectomy followed by an abscess and an episode of hypertensive encephalopathy) in this group. In both cases the patient recovered quickly.

There is necessarily great disorganization of the family's life. They may have to move house as the patient needs a room of his own in which to dialyse. During the early stages of treatment one parent (usually the mother) must devote herself to the patient alone, while she learns to run the dialysis. This means that the other children must be looked after by friends or relatives. There may be moderately severe financial sacrifices if the mother has to stop working. Travelling expenses and the cost of alteration of the home can be worrying, but are often recovered, at least in part. Even so, most families lose financially. Of all the members of the family, it is the mother who is affected most. All her social activities have to be drastically reduced; this can be a great hardship over a prolonged period. All mothers and some fathers had noticed an increase in anxiety in themselves rather than in the patient. Some parents thought that dialysis had put an increased strain on their marriage. By contrast, the sibs of the patient seem to suffer very little and to adapt quickly. Their mothers reported that they were no more difficult to manage and that their school performance had not suffered.

The patient always became more dependent on his or her mother, who in turn seemed to accept this as natural and encouraged it. The medical staff can help a great deal by simple reassurance and advice, especially with the teenage patients.

All patients (except Case 2) attend school regularly. One misses $1 \frac{1}{2}$ days each week because he has to travel 60 miles twice a week to the unit for dialysis. In theory, the patients on home dialysis attend school full-time. In practice, they miss an occasional morning because they feel ill for a few hours after a dialysis, during which they have received vigorous ultrafiltration, or have had a pyrogenic reaction. Case 2 lost so much schooling during her predialysis illness that she is now trying a correspondence course without much success; she finds it difficult to maintain concentration for long. All the other patients have achieved a comparable academic standard to their standard before illness. School attendance is vastly improved on that of patients with chronic renal failure.

Limitations of physical activity are imposed by the shunt, which has to be kept clean and dry and protected from violence.

\section{Transplantation}

Results. Eight grafts were given to 6 patients (see Table II). The operation itself presented few

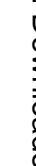


vho Have Received Renal Homotransplants

\begin{tabular}{|c|c|c|c|c|c|c|}
\hline \multirow{2}{*}{$\begin{array}{l}\text { Number } \\
\text { of } \\
\text { Mismatches }\end{array}$} & \multirow{2}{*}{$\begin{array}{c}\text { Graft } \\
\text { Survival } \\
\text { (mth) }\end{array}$} & \multirow{2}{*}{ Rejection Episodes } & \multirow{2}{*}{$\begin{array}{c}\text { Lowest Serum } \\
\text { Creatinine } \\
\text { Achieved }\end{array}$} & \multirow{2}{*}{$\begin{array}{c}\text { Present } \\
\text { Serum } \\
\text { Creatinine }\end{array}$} & \multicolumn{2}{|c|}{ Present Immunosuppression } \\
\hline & & & & & Prednisone & Azathioprine \\
\hline $\begin{array}{l}1 \\
1 \\
2 \\
1 \\
1 \\
1 \\
1 \\
1\end{array}$ & $\begin{array}{c}16 \\
24 \\
10 \\
1 \frac{1}{2} \\
14 \\
5 \frac{1}{2} \\
8 \\
5 \frac{1}{2}\end{array}$ & $\begin{array}{l}\text { Nil } \\
\text { Chronic rejection from } 9 \mathrm{mth} \\
\text { Acute rejection at } 9 \mathrm{mth} \\
\text { Nil } \\
\text { Chronic rejection from } 9 \mathrm{mth} \\
\text { Nil } \\
\text { Acute rejection at } 6 \mathrm{wk} \\
\text { Acute rejection at } 4 \mathrm{mth}\end{array}$ & $\begin{array}{l}0 \cdot 9 \\
1 \cdot 0 \\
1 \cdot 8 \\
0 \cdot 7 \\
1 \cdot 5 \\
1 \cdot 1 \\
1 \cdot 2 \\
1 \cdot 4\end{array}$ & $\begin{array}{l}1 \cdot 4 \\
3 \cdot 7 \\
0 \cdot \overline{7} \\
\frac{1}{1 \cdot 1} \\
1 \cdot 4 \\
5 \cdot 6\end{array}$ & $\begin{array}{r}10 \\
\frac{15}{10} \\
\frac{5}{5} \\
10\end{array}$ & $\begin{array}{l}100 \\
\frac{100}{100} \\
\frac{75}{25 \star} \\
100\end{array}$ \\
\hline
\end{tabular}

= Cadaver. $\quad$ «This patient underwent immunological enhancement.

difficulties attributable to the size of the patients. All but one involved the insertion of an adult kidney. Only in Case 10 was it necessary to use an unusual position for the kidney which lay most easily to the left of the midline with its vessels attached to the right iliac vessels. The only technical complications were a postoperative perirenal haemotoma which became infected in Case 8, and an arterial anastomotic stenosis which required a patch angioplasty in Case 9 six months after his first transplant.

Kidney grafts functioned immediately in 3 patients. 2 to $\mathbf{4 0}$ days' dialysis were required after the other 6 transplants before diuresis occurred. The patients themselves made a good recovery and 2 were discharged within 2 weeks of operation.

After discharge all returned to school full-time, and to full physical activity within 3 months. However, 3 patients (Cases 8, 9, and 11) developed sufficient renal failure to restrict their activities. 2 have rejected their grafts which were removed after 10 months in Case 8 and after 14 months in Case 9. After the nephrectomy, the former had a severe haematemesis which was thought to be attributable to her steroid therapy. During the terminal failure of his first graft, the latter developed hypertension (diastolic pressure about $130 \mathrm{mmHg}$ ). This was also, in part, due to steroid therapy and resolved after transplant nephrectomy. Both returned to intermittent dialysis and subsequently were retransplanted and now have excellent renal function. Cases 7 and 11 have impaired renal function due to chronic rejection but are still at school.

The other 2 (Cases 6 and 10) have had an excellent result and have returned to normal activities.

Growth and puberty. The 6 patients in this group presented with chronic renal failure. Cases 8 and 9 were below the third centile on starting dialysis. Since his second transplant the latter has begun a growth spurt. $\mathrm{He}$ is on $5 \mathrm{mg}$ prednisone a day. Case 10 is on the same dose of prednisone and is growing along the 3rd centile. Case 6 started on the 50th centile and had a transplant 16 months ago. She has only grown $1 \mathrm{~cm}$ in that time and is now below the 25th centile. She is on a stable dose of $10 \mathrm{mg}$ prednisone a day. Case 7 started just below the 50th centile and has only grown $2 \mathrm{~cm}$ and is now just above the 3rd centile. She has a failing graft and is on $15 \mathrm{mg}$ prednisone a day. Lastly, Case 11 started on the 25th centile and continues to grow along it, despite quite severe renal failure and prednisone $10 \mathrm{mg} /$ day.

Two boys are prepubertal and the third has grown pubic hair since his second transplant. Of the 3 girls, 1 has started to menstruate, and the other 2 have developed secondary sexual characteristics but have not yet started to menstruate.

\section{Discussion}

This is a small series but the results show that it is possible to prolong the lives of children beyond terminal renal failure.

Long-term haemodialysis. Shaldon et al. (1969), Fine et al. (1969), and Broyer et al. (1970) report a total of 45 children aged $1 \frac{1}{2}$ to 20 years dialysed for a total of 347 patient months. There were no deaths in this group. About half the patients had suffered some form of glomerulonephritis; most of the remainder had had pyelonephritis. Two had suffered from the haemolytic uraemic syndrome. Whatever the aetiology of the renal failure, they made a quick symptomatic recovery once they started haemodialysis. In a survey of 35 British units (November, 1970) it was found that in 18 units, 74 children received a total of 740 patient-months on dialysis. There have 
been 7 deaths on dialysis, or 1 death in every 106 patient-months. These children were all treated in units primarily designed for adults.

Most units dialyse children in hospital as a preparation for transplantation (Potter et al., 1970; Fine et al., 1969). Shaldon et al. (1969) has shown, and our results confirm, that children can be dialysed at home. It has not proved difficult to teach the mother to run the dialysis. The quality of life is good in the short term, but there are undoubted disadvantages. These include an unusual dependence on the mother, anaemia, the presence of a shunt, and some dietary restrictions (e.g. chocolate), and the physical necessity of 20 to 36 hours of dialysis every week. This makes it very difficult for the family to arrange a holiday, to say nothing of the disruption of the daily routine. However, these handicaps are considerably less than those resulting from chronic renal failure.

The long-term results of dialysis are still largely unknown. While at least 7 patients have grown during long-term dialysis (Shaldon et al., 1969; Broyer et al., 1970), catch-up growth is rare and parallel growth unusual. Only one of our patients is growing satisfactorily. Shaldon has stressed that growth may only be attained by frequent dialysis and the liberal diet that this permits. Too much dialysis may make the family's life unbearable. At the moment it seems that a high calorie diet $(60-70 \mathrm{cal} / \mathrm{kg}$ per day) with a high protein intake (above $1.5 \mathrm{~g} / \mathrm{kg}$ per day) and at least thrice weekly dialysis of 10 hours each time are necessary to attain growth in older children (Fine et al., 1970; M. A. Holliday, 1970, personal communication).
The only patient of ours to grow has had the most dialysis ( $3 \times 12$ hours per week). Lindsay et al. (1969), Broyer et al. (1970), and Snodgrass et al. (1970) have shown that there was a normal increase in growth hormone levels in response to hypoglycaemia in both children and adults on regular dialysis, but as Broyer et al. (1970) points out, this response did not correlate with the growth achieved.

There is even less evidence to show whether the sexual development of these children is normal and how management might affect it. 2 of Shaldon's 3 children passed puberty while on dialysis (Shaldon et al., 1969). A proportion of adult women on dialysis menstruate and an occasional male patient has fathered a child (Elstein, Smith, and Curtis, 1969). Our study has not yet added to this information.

Transplantation. The results of transplantation are more varied. The best result enables a child to lead a normal life with the minimum of medical supervision. Potter et al. (1970) and Fine et al. (1970) have shown that normal growth can occur and that puberty can be achieved provided that the average dose of prednisone is below $10 \mathrm{mg} / \mathrm{m}^{2}$ per day. Our results are not as clear cut as this (see Table III). One of our patients has led a normal life for over a year. Three others have good renal function 8,5 , and $1 \frac{1}{2}$ months after transplant, and are leading normal lives.

At the other end of the scale, transplantation can lead to the misery of renal failure associated with massive amounts of immunosuppressive therapy and frequent hospital admissions. Such children

TABLE III

Details of Growth in Height and Weight of 11 Children

\begin{tabular}{|c|c|c|c|c|c|c|c|c|}
\hline Case No. & $\begin{array}{l}\text { Height on } \\
\text { Starting } \\
\text { (cm) }\end{array}$ & Centile & $\begin{array}{l}\text { Present } \\
\text { Height } \\
(\mathrm{cm})\end{array}$ & Centile & $\begin{array}{l}\text { Weight on } \\
\text { Starting } \\
(\mathbf{k g})\end{array}$ & $\begin{array}{c}\text { Present } \\
\text { Weight } \\
(\mathbf{k g})\end{array}$ & \multicolumn{2}{|c|}{ Hours on Dialysis/wk } \\
\hline $\begin{array}{l}1 \\
2 \\
3 \\
4 \\
5\end{array}$ & $\begin{array}{l}159 \\
167 \\
152 \cdot 5 \\
\mathrm{NK} \\
122\end{array}$ & $\begin{array}{r}65 \\
84 \\
35 \\
<3\end{array}$ & $\begin{array}{l}159 \\
167 \\
152 \cdot 5 \\
118^{\star} \\
123\end{array}$ & $\begin{array}{r}25 \\
75 \\
25 \\
25 \\
<3\end{array}$ & $\begin{array}{l}37 \cdot 6 \\
44 \\
36 \cdot 7 \\
19 \cdot 5 \\
14 \cdot 6\end{array}$ & $\begin{array}{l}47 \cdot 5 \\
53 \cdot 2 \\
45 \cdot 7 \\
21 \cdot 9 \\
20\end{array}$ & \multicolumn{2}{|c|}{$\begin{array}{r}10 \times 3 \\
10 \times 2 \\
13 \times 2 \\
12 \times 3 \\
7 \times 3\end{array}$} \\
\hline & & & & & & & \multicolumn{2}{|c|}{ Present Dose } \\
\hline & & & & & & & Prednisone & Azathioprine \\
\hline $\begin{array}{r}6 \\
7 \\
8 \\
9 \\
10 \\
11\end{array}$ & $\begin{array}{l}155 \cdot 5 \\
141 \\
\text { NK } \\
126 \\
\text { NK } \\
129\end{array}$ & $\begin{array}{r}50 \\
40 \\
<3 \\
25\end{array}$ & $\begin{array}{l}155 \cdot 5 \\
143 \\
144 \\
134 \\
126 \\
132 \cdot 5\end{array}$ & $\begin{array}{r}20 \\
5 \\
<3 \\
<3 \\
3 \\
25\end{array}$ & $\begin{array}{l}38 \\
36 \cdot 4 \\
\mathrm{NK} \\
27 \cdot 7 \\
25 \cdot 0 \\
25 \cdot 0\end{array}$ & $\begin{array}{l}49 \\
47 \\
35 \\
30 \\
32 \\
32\end{array}$ & $\begin{array}{r}10 \\
15 \\
10 \\
5 \\
5 \\
10\end{array}$ & $\begin{array}{r}100 \\
100 \\
100 \\
25 \\
25 \\
100\end{array}$ \\
\hline
\end{tabular}

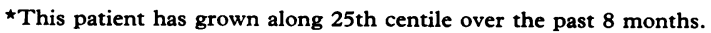

$\mathrm{NK}=$ Not known. 


\section{Treatment of Terminal Renal Failure in Children by Home Dialysis and Transplantation 463}

do not grow. They suffer all the unwelcome effects of large doses of steroids and azathioprine. The quality of their lives may be much worse than ever before. Four of our patients have or have had some degree of renal failure (see Table II). Two have undergone transplant nephrectomy and retransplantation. The emotional problems associated with this sequence of events can easily be imagined (Frances et al., 1970). In fact both patients proved impressively resilient.

We have had no deaths in this small group. Potter et al. (1970) and Fine et al. (1970) have transplanted a total of $\mathbf{4 8}$ children under the age of 17 years. 7 have died, one from a recurrence of a Wilms' tumour. 6 died in the first 7 months after transplantation, and 5 of these dead children had received a cadaver's kidney. In the survey of dialysis and transplantation units mentioned above, 45 children have been transplanted in 13 units, 29 receiving cadavers' kidneys and 16 from live donors. 12 children ( $27 \%$ ) died, only 2 being the recipient of a kidney from a live donor. 3 more children are back on dialysis. Therefore 15/45 renal transplants have failed (this is the same as for adults (Gurland et al., 1970)).

The mortality rate is therefore much higher in the cadaver transplanted group than in the haemodialysis group. It may soon be reduced by avoiding present methods of immunosuppression, for example by using ALG or immune enhancement (Lancet, 1969). Well-matched kidneys (Batchelor, and Joysey, 1969) and the Rosette Inhibition Test (Munro et al., 1971) may reduce the amount of steroids given to these patients. Alternate-day steroid therapy has been reported to permit better growth (Reed, Lucas, and Cohn, 1970) but this regimen may not give satisfactory immunosuppression (MacGregor et al., 1969). In contrast, the future developments of long-term dialysis are unlikely to lead to any radical improvement in this type of treatment.

In summary, the two methods each have their own advantages and disadvantages. The best results of transplantation are superior to those of dialysis, but the mortality and morbidity rates are higher (Cameron et al., 1970). The choice of treatment offered to any particular child must depend on a careful assessment of the social, psychological, and medical factors.

The ethical problems revolve around who should be offered a rare and expensive form of treatment. This presupposes that there is competition for each place; this has not been so in our unit as yet. More serious objections involve the long-term prognosis of these children. This is unknown at present, but short-term results are sufficiently encouraging to continue. It is probably best that the treatment be carried out in a few busy dialysis and transplantation units with some access to skilled paediatric advice (Meadow et al., 1970).

We would like to thank the paediatricians who referred these patients to us, and the staff of the dialysis, home dialysis, and transplant units upon whom these patients depend.

\section{REFERENCES}

Batchelor, J. R., Ellis, F., French, M. E., Bewick, M., Cameron, J. S., and Ogg, C. S. (1970). Immunological enhancement of human kidney graft. Lancet, 2, 1007.

Batchelor, J. R., and Joysey, V. C. (1969). Influence of H.L-A. incompatability on cadaveric renal transplantation. Lancet, 1,790

Brescia, M. J., Cimino, J. E., Appel, K., and Hurwich, B. J. (1966). Chronic hemodialysis using venipuncture and a surgically created arteriovenous fistula. New England fournal of Medicine, 275, 1089.

British Medicical fournal (1969). Leader. Hypertension in patients on regular dialysis, 3, 669.

Broyer, M., Loirat, C., Kleinknecht, C., Rappaport, R., and Raimbault, G. (1970). Eighteen months experience with haemodialysis in children. Proceedings of the European Dialysis and Transplant Association, 7, 261.

Cameron, J. S., Ellis, F. G., Ogg, C. S., Bewick, M., Boulton Jones, J. M., Robinson, R. O., and Harrison, J. (1970). A comparison of mortality and rehabilitation in regular dialysis and transplantation. Proceedings of the European Dialysis and Transplant Association, 7, 25.

Chisholm, G. D., Papadimitriou, M., Kutatilake, A. E., and Shackman, R. (1969). The diagnosis of rejection of renal allotransplants in man. Lancet, 1, 904.

Elstein, M., Smith, E. K. M., and Curtis, J. R. (1969). Reproductive potential of patients treated by maintenance haemodialysis. British Medical fournal, 2, 734.

Fam, A. G., Howey, S., Taylor, J. J., and Hocken, A. G. (1970). Iron absorption in chronic renal failure. Proceedings of the European Dialysis and Transplant Association, 7, 81.

Fine, R. N., DePalma, J. R., Gordon, A., Maxwell, M. H., Grushkin, C. M., and Lieberman, E. (1969). Haemodialysis in children. Proceedings of the European Dialysis and Transplant Association, $6,149$.

Fine, R. N., Korsch, B. M., Stiles, Q., Riddell, H., Edelbrock, H. H., Brennan, L. P., Grushkin, C. M., and Lieberman, E. (1970). Renal homotransplantation in children. Fournal of Pediatrics, 76, 347.

Frances, V. R., Fine, R. N., and Korsch, B. M. (1970). Psychologic and social adjustment to extended haemodialysis and renal homotransplantation in 42 children. Proceedings of the European Dialysis and Transplant Association, 7, 366.

Gurland, H. J., Härleen, H., Henze, H., and Spoek, M. G. (1970). Intermittent dialysis and renal transplantation in Europe: survival rates. Proceedings of the European Dialysis and Transplant Association, 7, 20.

Lancet (1969). Leader. Graft survival and immunological enhancement, 2, 1111 .

Lancet (1970). Leader. Mortality during regular dialysis treatment, 2, 968.

Lindsay, R. M., Webster, M. H. C., Duguid, W. P., and Kennedy, A. C. (1969). Growth hormone secretion in the regular dialysis patient. Proceedings of the European Dialysis and Transplant Association, 6, 157.

Linstedt, E., Lindergård, B., and Lindholm, T. (1970). Haemodialysis in children. Lancet, 1, 1057.

MacGregor, R. R., Sheagren, J. N., Lipsett, M. B., and Wolff, S. M. (1969). Alternate-day prednisolone therapy. New England fournal of Medicine, 280, 1427.

Meadow, R., Cameron, J. S., and Ogg, C. (1970). Regional service for acute and chronic dialysis of children. Lancet, 2, 707. 
Munro, A., Bewick, M., Manuel, L., Cameron, J. S., Boulton Jones, J. M., Ellis, F. G., and Ogg, C. S. (1971). Clinical evaluation of the rosette inhibition test. British Medical fournal. (In the press.)

Politano, V. A., and Leadbetter, W. F. (1958). An operative technique for the correction of vesicoureteral reflux. Fournal of Urology, 79, 932.

Potter, D., Belzer, F. O., Rames, L., Holliday, M. A., Kountz, S. L., and Najarian, J. S. (1970). The treatment of chronic uremia in childhood. I. Transplantation. Pediatrics, 45, 432.

Reed, W. P., Lucas, Z. J., and Cohn, R. (1970). Alternate-day prednisone therapy after renal transplantation. Lancet, 1 , 747.

Shaldon, S., Shaldon, J., McInnes, S., Macdonald, H., and Oag, D. (1969). Long-term maintenance domestic haemodialysis in children. Proceedings of the European Dialysis and Transplant Association, 6, 145.

Snodgrass, G., Robinson, R. O., Mashiter, K., Ogg, C. S., and Cameron, J. S. (1970). The disappearance of immune reactive insulin in anephric man and the effects on glucose, cortisol and growth hormone levels. Proceedings of the European Dialysis and Transplant Association, 7, 225.

Vertes, V., Cangiano, J. L., Berman, L. B., and Gould, A. (1969). Hypertension in end-stage renal disease. New England fournal of Medicine, 280, 978.

Correspondence to Dr. J. M. Boulton Jones, Guy's Hospital, London S.E.1.

\section{Addendum}

Since this manuscript was prepared, a further six months' follow-up has accumulated; the 11 patients have now been followed for 15 to 32 months. Case 3 has dialysed three months in the home and since going home has become Australia antigen positive. All five male patients have continued parallel growth, gaining a further 0.5 to $3.5 \mathrm{~cm}$ in height. The girls have grown less well; only 1 of the 6 girls have grown. Case 7 has gained a further $1.5 \mathrm{~cm}$. However, of the others, only Case 5 is prepubertal.

Unfortunately Case 11 died from sepsis in May 1971 before his second transplant (April 1971) could function. Case 1 has just died (June 1971) of cardiac arrest during a dialysis; no cause could be determined.

A recent important paper has brought the experience of cadaver transplantation in Los Angeles up to date (Fine et al., 1971) and the results presented are encouraging.

\section{REFERENCE}

Fine, R. N., Edelbrock, H. H., Brennan, L. P., Grushkin, C. M., Korsch, B. M., Riddell, H., Stiles, Q., and Lieberman, E. (1971). Cadaveric renal transplantation in children. Lancet, 